\title{
RISING FAMILY INCOME INEQUALITY \\ IN THE UNITED STATES, 1968-2000: \\ IMPACTS OF CHANGING LABOR SUPPLY, WAGES, AND FAMILY STRUCTURE
}

Chulhee Lee

Working Paper 11836 
NBER WORKING PAPER SERIES

\title{
RISING FAMILY INCOME INEQUALITY \\ IN THE UNITED STATES, 1968-2000: \\ IMPACTS OF CHANGING LABOR SUPPLY, WAGES, AND FAMILY STRUCTURE
}

\author{
Chulhee Lee \\ Working Paper 11836 \\ http://www.nber.org/papers/w11836 \\ NATIONAL BUREAU OF ECONOMIC RESEARCH \\ 1050 Massachusetts Avenue \\ Cambridge, MA 02138 \\ December 2005
}

I thank Yongsung Chang and Robert W. Fogel for their helpful comments and suggestions on earlier drafts, and Jihyun Kim for her research assistance. I gratefully acknowledge the financial support provided by National Institute on Aging, the National Institute of Health (P01 AG10120), and Korea Research Foundation Grant (KRF-2003-041-B00104). The views expressed herein are those of the author(s) and do not necessarily reflect the views of the National Bureau of Economic Research.

(C)2005 by Chulhee Lee. All rights reserved. Short sections of text, not to exceed two paragraphs, may be quoted without explicit permission provided that full credit, including (C) notice, is given to the source. 
Rising Family Income Inequality in the United States, 1968-2000: Impacts of Changing Labor

Supply, Wages, and Family Structure

Chulhee Lee

NBER Working Paper No. 11836

December 2005

JEL No. J2, E2, N3

\begin{abstract}
$\underline{\text { ABSTRACT }}$
This study estimates what fraction of the rise in family income inequality in the United States between 1968 and 2000 is accounted for by change in each of the family income components such as wages, employment, and hours worked of family heads and spouses, family structure, and other incomes. The increased disparities in other incomes and labor supply account for, respectively, 29 percent and 28 percent of the rise in the difference in income between the top $10_{\mathrm{th}}$ and bottom $10_{\mathrm{th}}$ families. Structural changes in wages, largely regarded as the major culprit of the increase in income inequality, explain less than a quarter of the rise in the measure of family income inequality. Changing fraction of families with both husband and wife and changes in the composition of the income sources account for 11 percent and 16 percent, respectively, of the widening of the income gap. The relative importance of the effect of changing labor supply declined over time, while that of wage changes increased. For the upper half of the income distribution, wage changes were the dominant cause of the increase in the gap between the richest 10 th and middle-income families. For the lower half of the income distribution, in sharp contrast, changes in labor supply and other incomes were the principal causes of the growing distance between the poor and middle-income families.

Chulhee Lee

School of Economics

Seoul National University

Seoul, Korea

and NBER

chullee@snu.ac.kr
\end{abstract}




\section{Introduction}

Rising income inequality is one of the most marked features of the U.S. economy in the era of globalization and IT revolution. ${ }^{2}$ Over the last couple of decades, an extensive literature has been accumulated regarding the patterns and causes of the growing disparities in incomes. The primary focus of recent studies has been on changing dispersions in individual wages between and within various demographic groups possessing different human capital attributes. Some major explanations for the widening of wage gap between high- and low-skilled workers are: technological changes, international trade, transfers abroad of production activities, inflow of lessskilled immigrants, degraded quality of education, decline of labor unions, and deregulations of industries. ${ }^{3}$

Although it is now much better understood how the wage structure transformed over time and what produced the change, thanks to the large body of evidence suggested previous studies, it is less clear how the increased income inequality affected the distribution of the wellbeing of individuals. In particular, it is striking that only a few studies have rigorously documented the changing distribution of family income. Given that family members jointly make decisions on labor supply, pool their earnings, and share family resources, family income is perhaps a better measure of material wellbeing of a person than his or her own wages. As in the case of individual wages and earnings, the family income disparity in the United States has sharply widened over the last several decades. ${ }^{4}$ One cannot simply assume that rising wage inequality is the main story behind the increase in family income inequality because family income is

\footnotetext{
${ }^{2}$ See Levy and Murnane (1992) and Gottschalk (1997) for the patterns of rising inequalities in various labor-market outcomes.

${ }^{3}$ See Hunt (1992) and Borjas, Freeman, and Katz (1997) for the impacts of the inflow of immigrants; Wood (1994), Borjas, Freeman, and Katz (1992, 1997), and Sachs and Shatz (1994) for the effects of international trades; Freenstra and Hanson (1999) and Miller (2001) for the roles of international outsourcing of productions; Berman, Bound, and Griliches (1994), Krueger (1993), Autor, Katz, and Krueger (1998), and Doms, Dunne, and Troske (1997), Bresnahn, Brynjolfsson, and Hitt (2002) for the impacts of technological changes; and Freeman and Katz (1995), Gottschalk and Smeeding (1997), OECD (1996), and Fortin and Lemieux (1997) for the influences of institutional changes.

${ }^{4}$ Between 1970 and 2000, for instance, the share of the aggregate income received by the lowest fifth families fell from 5.4 percent to 4.3 percent. In contrast, the share of income earned by the top 5 percent families increased from 15.6 percent to 21.1 percent during the same decades (U.S. Bureau of the Census 1996, No. 719; U.S. Bureau of the Census 2004, No. 672).
} 
determined by many other factors in addition to individual wages. These factors include employment and hours worked of each of family members, family structure, and nonlabor incomes.

Only a small number of studies have paid attention to the effect of changing labor supply on income inequality. Burtless $(1990,1993)$ and Moffitt (1990) reported that the growth in annual earnings inequality for male workers during the 1970s and 1980s was primarily due to growing inequality in hourly wage rates. On the other hand, Haveman (1996) suggested that the increase in earnings inequality between 1973 and 1988 among working-age men was largely produced by increased variability in the amount that potential breadwinners worked. ${ }^{5}$ Hyslop (2001) reported that, among married working couples, behavioral labor supply responses to wage changes explain 20 percent of the rise in family earnings inequality in the early 1980 s. $^{6}$ Lee (2001) computed that changes in labor market activity of family heads accounted for half of the increased gap between families in the top and bottom income deciles between 1969 and $1989 .^{7}$

The previous studies on income inequality have largely focused on male workers. However, patterns of individual labor force participation and of hours of work need to be understood in the context of joint decisions made by family members. For example, if income effect is strong, fewer working hours or lower wages of a family head could be supplemented by increased hours worked by the spouse or other family members. The existing literature is nearly silent about how changes in employment and hours of family head and spouse jointly contributed to the family income inequality. Burtless (1993) estimated the contribution of the employment and hours changes by comparing the actual and counterfactual changes in Gini-ratio for the periods 1969-1979. However, his study, after all, dealt with individual earnings of men and women rather

\footnotetext{
${ }^{5}$ These studies use variance of logarithm (VLN) of earnings as the measure of inequality. They decompose the VLN of earnings into (1) VLN of wage rates, (2) VLN of hours worked, and (3) a covariance term between the two. They then observed change in each factor over time to assess its relative contribution to the increase in the VLN of earnings.

${ }^{6}$ The main evidence of this study comes from the own- and cross-covariance structures of wages and earnings of couples in the 1979-1985 Panel Study of Income Dynamics (PSID).

${ }^{7}$ This study estimates a counterfactual measure of the family income inequality for 1989 that would have resulted, had the employment and hours distribution as of 1969 remained unchanged.
} 
than family earnings. ${ }^{8}$ Hyslop (2001) found that married men and women tended to increase (decrease) the hours in responses to diminished (increased) earnings of their spouses. Based exclusively on a sample of employed couples, however, this study fails to provide evidence regarding the effect of changing pattern of employment on family income inequality.

There are a few studies that enable us to predict how changing pattern of work affected the family income inequality. Decline in employment was particularly severe among less-educated and low-wage men between 1967 and 1988 (Juhn 1992). The rise in two-earner couples has been more pronounced in families in which the husband's earnings are higher (Cancian, Danziger, and Gottschalk 1993). Employment and earnings gains have been greatest for wives of middle- and high-wage men (Juhn and Murphy 1997). The inter-spousal correlation of wages, hours, and employment increased between 1979 and 1987 (Blackburn and Bloom 1995). Finally, as noted above, the intertemporal substitution effect of a wage change dominated its income effect for married women in the early 1980s (Hyslop 2001). These changes in employment and earnings patterns of men and women should have increased the family income inequality to some extent. However, the magnitude of the joint effect is unclear.

The purpose of this paper is to examine what fraction of the rise in family income inequality in the United States between 1968 and 2000 is accounted for by change in each of the following components of the family income: (1) employment of the head, (2) the hours worked of the head, (3) the wage rate of the head, (4) marital status of the head, (5) employment of the spouse, (6) the hours worked of the spouse, (7) the wage rate of the spouse, (8) the incomes from other sources than the earnings of the head and the spouse, and (9) the fraction of the family income coming from a particular source. More specifically, I estimate what percentage of the change in the measure of family income inequality (defined in this study as the difference in the log of the average income between families in different income deciles) is attributable to the change in the above factors for the period between 1969 and 1999 and the three subperiods, 1969-1979, 1979-1989, and1989-1999.

\footnotetext{
${ }^{8} \mathrm{He}$ ranked individuals into earnings quintiles according to family earnings rather than individual earnings, and calculates counterfactual mean earnings for each earnings quintile, assuming no change in the mean employment rate and hours of work in each earnings group.
} 
This study is distinct from other studies in the following respects. First, this study explicitly considers at the same time all potentially important factors of the total family income inequality. To my knowledge, this study is the first that combines the effects of changing wage, employment, hours worked, family structure, and composition of income into a single decomposition framework. Second, my study compares results based on several different samples of populations, namely, (1) all families headed by persons aged 18 to 64, (2) all households including families and single householders, (3) families headed by persons aged 25 to 55, and (4) families headed by males aged 25 to 55 . Using alternative samples not only enable me to avoid sample-selection biases but also help interpret the results more accurately. Finally, my study covers the entire three decades during which the family income inequality increased, and compares the results for each decade within the period under study. This will help understand how the mechanisms of rising income inequality changed over time.

The organization of this paper is as follows: I begin with developing a method of decomposing a change in family income in the next section. Section 3 introduces the data used in the analysis. Section 4 describes the patterns of changes in the elements of family income inequality between 1969 and 1999. In section 5, I present the results of the decompositions that provide explanations for how each of the components of family income contributed to the changes in income inequality. I also examine how the results change where alternative measures of inequality are used. Section 6 compares the results based on several different samples. The final section summarizes the paper.

\section{Analytical Framework}

I begin with a decomposition of total family income into several components. The definition of variable representing each of the components is given in Table 1. The average annual money income of households in a given income decile, denoted $N$, may be presented as

$$
\text { (1) } N \equiv H_{h} W_{h} P_{h}+H_{s} W_{s} P_{s} \delta+Q
$$


where $H_{h}, H_{s}, W_{h}$, and $W_{s}$ stand for the mean annual hours worked and the mean hourly wage rates for employed heads and spouses, respectively; $P_{h}$ and $P_{s}$ stand for the employment rates for heads and, if married, spouse; $\delta$ is the fraction of households in which both husband and wife are present; and finally, $Q$ stands for the mean incomes from other sources.

As the measure of income inequality, I use the difference in the log of average family income between two income deciles, say, the top and the bottom income deciles (denoted by $N^{*}$ ). That is, $N^{*}=\ln \left[N^{T O P}\right]-\ln \left[N^{\text {BOTTOM }}\right]$. Using an approximation, $N^{*}$ can be decomposed as shown in equation (1), where the asterisk denotes the difference in the $\log$ s of a variable in the top and bottom deciles of families. For example,

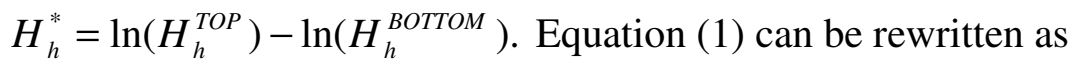

(2) $N^{*} \approx \Phi_{h}\left(H_{h}^{*}+W_{h}^{*}+P_{h}^{*}\right)+\Phi_{s}\left(H_{s}^{*}+W_{s}^{*}+P_{s}^{*}+\delta\right)+\Phi_{Q}\left(Q^{*}\right)$

where $\Phi$ denotes the weight of each of the three income sources. For example, $\Phi_{h}\left[=\left(H_{h} W_{h} P_{h}\right) / N\right]$ indicates the earnings of heads as a proportion of the total average family income.

It is possible to decompose the change in $N^{*}$ over time, in this case, say, between 1969 and 1999, by differentiating equation (2) totally, to obtain

$$
\begin{aligned}
& \Delta N^{*} \approx \Phi_{h} \Delta H_{h}^{*}+\Phi_{h} \Delta W_{h}^{*}+\Phi_{h} \Delta P_{h}^{*}+\Delta \Phi_{h}\left(H_{h}^{*}+W_{h}^{*}+P_{h}^{*}\right)+ \\
& \text { (3) } \Phi_{s} \Delta H_{s}^{*}+\Phi_{s} \Delta W_{s}^{*}+\Phi_{s} \Delta P_{s}^{*}+\Phi_{s} \Delta \delta^{*}+\Delta \Phi_{s}\left(H_{s}^{*}+W_{s}^{*}+P_{s}^{*}+\delta^{*}\right)+ \\
& \Phi_{Q} \Delta Q^{*}+\Delta \Phi_{Q} Q^{*}
\end{aligned}
$$

The first term on the right-hand side of equation (3), for example, represents the rate of change in the disparity in average hours worked by family heads in the top and bottom deciles, weighted by the relative share of family income derived from the earnings of the head. The estimate of this term indicates the relative contribution of the change in average working hours of heads to the rise in the measure of income inequality between 1969 and 1999. Likewise, the second and third terms show the relative contributions of 
changes in hourly wages and in the employment rate of heads, respectively. On the other hand, the fourth term represents the effect of changing weight, that is, the relative importance of earnings of family heads as a source of income. If earnings of family heads are more unequally distributed than other sources of income, an increase in the share of earnings of the head in the total family income would produce a rise in the magnitude of inequality.

It should be noted that I do not follow up the individual families over time using this method. I am only comparing the families in particular income group today with the families in that income category in the past, who are not necessarily the same. The questions to be answered using the method explained above is why the difference in income between rich and poor families today is much greater than it was thirty years ago. More specifically, this study examines how the gaps between today's rich and poor families in wages, employment, hours, other incomes, and family structure differ from the disparities in these factors between the rich and the poor in the past. The framework used in this study, however, can provide only limited hints as to why the distribution of these family income components changed over time. For instance, the rise in the disparities in employment and hours of heads and spouses may have resulted from individual families' behavioral responses to changes in economic conditions such as changing wage structure, which cannot be analyzed in the present framework. However, I believe it is important to understand first what happened even if it cannot be fully explained why it happened.

\section{Data}

The balance of this paper is based on data from Annual Demographic Files on the March Current Population Surveys (CPS, hereafter) for the survey years 1969 to 2001. Since most of the calculations below are based on annual earnings, weeks worked, and usual hours of work per week in the year previous to the survey, this study covers the calendar years 1968 to 2000 . The secular rise in the family income inequality started in the late 1960s and continued thereafter. Accordingly, I choose four bench-mark years, 1969, 1979, 1989, and 1999 to study long-term changes. The patterns of changes in the determining factors of family income inequality may be sensitive to the choice of the initial and end years (see, for example, Haveman 1996). I average three years of data 
centered around the bench-mark years to mitigate possible business cycle effects. Thus the averages I report for 1969, 1979, 1989, and 1999 are actually based on the 1968-70, 1978-80, 1988-90, and 1998-2000 CPS data.

The main unit of analysis used in this study is the family which is composed of two or more related persons. I limit the sample to families whose heads are at working ages (between 18 and 64). ${ }^{9}$ However, alternative sample selection may provide different results. ${ }^{10}$ The three decades under study have witnessed a great transformation in the living arrangement. As the fraction of non-family households greatly increased, the population covered by the sample composed of families should have diminished. Moreover, the working ages chosen here (18 to 64) may not be fully comparable across different cohorts because of the secular rise in college attendance and early retirement over the three decades. The increase in the proportion of female-headed families was also remarkable. In addition to the primary sample composed of families, for these reasons, I use several alternative samples covering different populations for testing the sensitivity of the result to the selection of the sample (see section 6).

Using these data sets, I calculate the components of the mean family income for each income decile, as explained above. The incomes and earnings are all converted into 1982-1984 dollars. The employment rate for family heads (spouses) is calculated dividing the number of those who worked at least one week last year by the number of all families for each income decile. I calculate annual hours of work by multiplying weeks and usual hours worked per week last year. ${ }^{11}$ I then estimate the annual hours

\footnotetext{
${ }^{9}$ I exclude a small number of families in which wife is recorded as the head because husband resides elsewhere while remaining married. The number of families covered by the sample for each year is 32,964 (1968), 31,499 (1969), 32,016 (1970), 33,842 (1978), 39,839 (1979), 39,842 (1980), 29,790 (1988), 32,316 (1989), 32,101 (1990), 31,188 (1998), 31,431 (1999), and 30,194 (2000).

${ }^{10}$ Karoly (1993) provides a good example of comparing the patterns of changing inequality based on different populations. Haveman (1996) noted that the increase in the variance of hours worked accounted for much larger proportion of the rise in the variance of log of male earnings for all males than it did for employed male workers.

${ }^{11}$ For this computation, the data from the 1968-1975 surveys are not comparable to the later surveys. For the early years, weeks worked last year are reported only on a bracketed basis and usual hours worked per week last year are not reported. In order to impute the continuous values for weeks worked last year, I divide the data from the 1976-1978 surveys into cells according to weeks worked and use the cell means for weeks worked as the corresponding week's data for the early years.
} 
worked for those employed in each income decile. ${ }^{12}$ Other income $(Q)$ is calculated as the difference between the average total household income and the average earnings of heads and spouses. Thus, it includes earnings of other household members and nonlabor incomes. ${ }^{13}$

\section{Changes in the Components of Household Income, 1969-1999}

Figures 1 to 7 and Appendix Table present the estimate of the mean total family income and each of the components of the mean family income for each income decile for 1969, 1979, 1989, and 1999. It is well documented that measures of family income inequality increased since the late 1960s and accelerated in the 1980s. The income gap between the top and bottom income deciles, the primary measure of household income inequality employed in this study, confirms the long-term rise in the family income inequality. As presented in Figure 1, the average income of the top 30 percent families increased rapidly while the incomes of low- and middle-income families stagnated or even declined. During the three decades, the average income of the top 10 percent families increased by 57 percent, as compared to a 40 percent decline among the families in the bottom income decile. In particular, the 1990s witnessed the most dramatic rise in the income disparity between rich and poor families. During the decade, the average income of the richest $10^{\text {th }}$ families increased by 30 percentage points

\footnotetext{
${ }^{12}$ For this calculation, the following method was used: First, I multiply hours worked in the week prior to the survey and weeks worked for those who worked at least one hour last week. This estimate of annual hours worked, denoted by $H^{L W}$, should differ from the actual annual hours, $H^{L Y}$, because (1) those who worked last week are not the same people as those who worked last year, and (2) hours worked last week may differ from usual hours worked last year. To see the size and pattern of the discrepancy, I compare $H^{L W}$ and $H^{L Y}$ using data from the 1976-1978 CPS. For each income decile, $H^{L W}$ is only slightly greater than $H^{L Y}$. More important, the relative size of $H^{L W}$ and $H^{L Y}$ is fairly stable across income deciles. I derive adjustment factors by dividing $H^{L Y}$ by $H^{L W}$ and apply them to the data from the 1969-1971 surveys to obtain more accurate estimate of annual hours worked. I also imputed annual hours worked for the early years following the procedure explained in Juhn (1992: appendix 1). As far as the average hours worked for each income decile is concerned, $H^{L W}$ is a closer approximation of $H^{L Y}$ than the imputed value.

${ }^{13}$ The average family size, reported in Appendix Table, does not differ much from one income declie to another. More importantly, the average family size of each income decile changed over time in a similar manner. Therefore, the patterns of changes in the family income components and their relative contributions to the rise in family income inequality that will be given below do not change much if the average per capita family income is considered.
} 
whereas the income of all families grew by about 6 percentage points. As a consequence, the difference in the log of the total family income between the top and bottom deciles, denoted $N^{*}$ above, increased by 0.96 ; more than half of the increase $(0.5355)$ was attributed to the change between 1989 and 1999.

Figure 2 suggests that shift in the hourly wage rates of family heads $\left(W_{h}\right)$ was probably not a powerful cause of the rise in the family income inequality until the 1990s. Wages for family heads slightly fell or remained unchanged for low- and middle-income families between 1969 and 1999. Although wages for the families in the top three income deciles slightly increased, the difference between high- and low-income families was relatively small. During the 1990s, on the other hand, the average wages for the top $10^{\text {th }}$ families greatly increased in sharp contrast to the relatively stable wage rates for the families in the rest of income distribution. Thus, the wage change should have increased the income inequality to a greater extent during the 1990s than it did in the previous two decades.

It is well documented in other studies how labor supply of men and women with different earnings potentials have changed over time (Juhn 1992, Cancian, Danziger, and Gottschalk 1993, Juhn and Murphy 1997). The present paper provides a picture of long-term changes in the elements of labor supply for a more broadly defined population, namely all families. The overall employment rate for family heads $\left(P_{h}\right)$ fell substantially over the three decades under investigation, particularly during the 1970s and the 1990s. The decline in $P_{h}$ was much greater for lower income families than for higher income families. For instance, $P_{h}$ fell 14 percentage points for the bottom income decile whereas it declined by 5 percentage points or less for the top three income deciles (Figure 3, and Table A1, row 3). Changes in annual hours worked for family heads $\left(H_{h}\right)$ exhibits a similar pattern. The decline in hours was particularly pronounced for the bottom two income deciles, especially from 1969 to 1989 (Figure 4 and row 4 of Table A1). We may predict from these patterns that uneven changes in $P_{h}$ and $H_{h}$ should be at least partly responsible for the rise in the family income inequality.

The fraction of husband and wife families $(\delta)$ families in lower half of income distribution fell considerably between 1969 and 1979, and rebounded during the next decades, except for the lowest income decile. In consequence, the decline in $\delta$ between 
1969 and 1989 is visible only for the lowest income decile. Between 1989 and 1999, $\delta$ sharply declined for all families, but more severely for lower-income families; $\delta$ remained relatively stable for the top two income deciles (row 9 of Appendix Table). In sum, family structure had changed in the direction to increase the family income inequality, especially between 1969 and 1979 and between 1989 and 1999. It should be kept in mind that this statistic disguises dramatic changes in the living arrangement and rising instability of the family because non-family households are excluded from the sample. I will return to this point later.

Over the period under study, the hourly wage for employed spouse $\left(W_{s}\right)$ increased much faster for high-income families than for lower-income families (Figure $5)$. The disparity in the spouses' wage growth between rich and poor families is much more pronounced than that of heads. For example, $W_{s}$ for the top income decile more than doubled between 1969 and 1999 whereas $W_{s}$ for the bottom three deciles remained little changed. This indicates that the change in $W_{s}$ should be a major source of the rise in the family income inequality over the three decades since 1969.

As the female labor-force participation rate increased, the proportion of employed spouses $\left(P_{s}\right)$ rose considerably. As illustrated by Figure 6, the rise in $P_{s}$ was generally greater among middle- and high-income families. For the top income decile, $P_{s}$ increased from 59 percent to 88 percent between 1969 and 1999. On the other hand, there was no gain for wives in the lowest $10^{\text {th }}$ families. This result indicates that the labor-force participation of spouses changed in the direction to magnify the family income inequality. The average annual hours of work of employed spouses $\left(H_{s}\right)$ has increased for families in all income deciles (Figure 7). In particular, wives in middleincome families increased the hours of work the most. This outcome tends to suggest that the effect of change in $H_{s}$ on the family income inequality, if any, should be small in magnitude.

\section{Decomposition of the Changes in Family Income Inequality}

The patterns of the changes over time in the components of household income, reviewed the preceding section, allow us to predict the direction of their contributions to 
the shift in household income inequality. For instance, hourly wages of heads should have been a minor factor that caused the decline in household income inequality between 1969 and 1989. Also, changes in the employment rate and the hours of work for heads should have substantially contributed to the widening of the income gap between the rich and the poor for the period under study. In the following two sections, I analyze in detail how changes in each of the components contributed to the shifts in the household income inequality. I begin with a baseline decomposition of the changes in the difference in the log of the total family income between the top and bottom income deciles based on equation (3).

\subsection{A Baseline Decomposition}

Table 2 presents the result of a baseline decomposition in which the samples of families headed by a head aged 18 to 64 are included and the difference in the log of income between the top and bottom income deciles is used as the measure of family income inequality. For the entire period between 1969 and 1999, in which the difference in the $\log$ of family income between the top and bottom deciles increased by 0.96 , changes in other incomes $(Q)$ and labor supply of heads and spouses $\left(P_{h}, H_{h}\right.$, and $\left.P_{s}\right)$ explain more than half of the rise in the measure of family income inequality (see the final column of Table 2).

The increased inequality in other incomes $(Q)$ accounts for 29 percent of the rise in the family income inequality between 1969 and 1999. Although $Q$ accounts for relatively small fraction of the total family income, the difference in $Q$ between the high- and low-income families increased so rapidly during the three decades to produce a strong impact on the rise in the overall family income inequality. ${ }^{14}$ As will be shown below, the effect of the change in other incomes is completely explained by the relative decline of other incomes of low-income families. Changes in employment and hours worked explain another 28 percent of the rise in the family income inequality between 1969 and 1999. In particular, changes in the hours worked and the employment rate for heads (that explain, respectively, 13 percent and 9 percent of the increase in the income

\footnotetext{
${ }^{14}$ In 1999, for example, $Q$ was 6196 dollars, about 17 percent of the mean total family income. Between 1969 and 1999, the rate of increase in $Q$ was much higher for the families in the top income decile (31 percentage points) than for the lowest income decile ( -44 percent).
} 
disparity) were major contributing factors, with change in the employment rate of spouses accounting for another 7 percent of the increase in the measure of inequality.

It is striking that structural changes in wages, largely regarded as the major culprit of the increase in income inequality, explain less than a quarter of the rise in the measure of family income inequality. The effects of the wage changes of heads and spouses were almost equally important. Changing family structure, measured by the fraction of families with both husband and wife $(\delta)$, was nontrivial factor of the rise in family income inequality. It accounts for 11 percent of the widening of the income gap between the top and bottom income deciles.

Changes in the composition of the income sources account for the remaining 16 percent of the rise in the measure of inequality. First of all, the rise in the share of spouses' earnings $\left(\Phi_{s}\right)$ strongly increased the measure of income inequality (see row 10 of Table 2). Since the percentage of families with married couples and the employment rate of spouses as well as the mean earnings of employed spouses are much lower for lower-income families than richer families, the disparity in spouses' earnings is much greater than the inequality in heads' earnings or other incomes. During the three decades under study, the share of spouses' earnings in the total family income increased from 13 percent to 31 percent. About two thirds of the effects of increased share of spouses' earnings were offset by the countervailing effects of the decline of the share of heads' earnings and the increase in the relative size of other incomes. ${ }^{15}$

The first three columns of Table 2 present the results of the decomposition for each of the three decades. According to the measure of inequality used in this study, the growing family income inequality accelerated during the 1990s. The upsurge in the income gap between the top and bottom income deciles between 1989 and 1999 was greater than the rise in the measure of inequality during the previous two decades combined.

The relative contribution of each of the components of family income considerably differed by decade. First of all, the relative importance of changing labor supply, especially the employment rate for heads, declined over time. During the 10

\footnotetext{
${ }^{15}$ The share of heads' earnings fell from $71 \%$ in 1969 to $52 \%$ in 1999 . The percentage of other incomes in the total family income increased from 15.9 percent in 1969 to 16.9 percent in 1999.
} 
years between 1969 and 1979, changes in employment and hours of heads and spouses accounted for nearly two thirds of the increase in the measure of income inequality. The proportion explained by changing labor supply decreased to 33 percent in 1979-1989, and to 28 percent by 1989-1999. On the other hand, the relative importance of the effect of changing wages increased over time: the percentage of the rise in the measure of inequality accounted for by wage changes was 10 percent in the 1970s, 4 percent in the 1980s, and 39 percent in the 1990s. The relative impact of changing distribution of other incomes $(Q)$ decreased over time.

\subsection{Right Tail vs. Left Tail of the Income Distribution}

A widening of the income disparity between the top and bottom income deciles could result from either a faster growth of income of the richest $10^{\text {th }}$ families or deterioration of the position of the lowest $10^{\text {th }}$ families, in comparison with the families in the middle. Likewise, the relative contribution of each of the components of family income could come from either left or right tail of the income distribution. Similar decompositions, also based on equation (3), are conducted separately for the differences in the log of income between the top $10^{\text {th }}$ and the average, and between the average and the bottom $10^{\text {th }}$ families. The results are reported in Tables 3 and 4.

The results suggest that 70 percent of the increase in the income difference between the top and bottom $10^{\text {th }}$ families were produced by deterioration of the position of the poorest $10^{\text {th }}$ relative to the families in the middle. During the decade between 1969 and 1979, in particular, the widening of the income disparity between the rich and poor families is completely explained by the relative decline of the bottom $10^{\text {th }}$ families. This indicates that the sharp rise of the family income inequality was largely due to the collapse of low-income families.

For the upper half of the income distribution, wage changes were the dominant cause of the increase in the measure of family income inequality. Changing heads' wages account for more than half of the increase in the difference between the incomes of the top 10 percent families and the average income; changing wages of spouses explain another 28 percent. The change in the proportion of families with both husband and wife was the other major factor of rising income inequality. The change in other incomes did not increase the measure of family income inequality. The overall effects of 
changes in labor supply and the composition of income sources were trivial.

For the lower half of the income distribution, in sharp contrast to the result for the upper half, changes in labor supply and other incomes were the principal causes of the growing distance between the poor and middle-income families. Shifts in employment and hours worked account for 36 percent of the increase in the difference between the incomes of the lowest 10th families and the average income. Change in other income accounts for 38 percent, indicating that the effect of change in other income reported in Table 2 is completely explained by the relative decline of other incomes of low-income families. Only 8 percent of the increase in the measure of inequality was attributable to wage changes. Changes in the composition of income sources and the proportion of families with both husband and wife explain 12 percent and 11 percent of the rising income disparity between the families in the middle and those at the bottom, respectively.

\subsection{Income Disparity between the $2^{\text {nd }}$ and $9^{\text {th }}$ Deciles}

The difference in the log of income between the top and bottom $10^{\text {th }}$ families, used above as the measure of household income inequality, may not deliver the full picture of changing inequality. By focusing on the gap between the richest and the poorest, in particular, it fails to capture any changes in the middle of the income distribution. In order to supplement this weakness at least partially, a similar decomposition method is applied to the difference in income between the second and ninth income deciles. The result is reported in Table 5 .

The rise in the difference in the log of income between the second and ninth deciles between 1969 and 1999 (0.5477) was about 60 percent in magnitude of the increased income gap between the highest and lowest $10^{\text {th }}$ families. The relative importance of the effect of each income component is considerably different between the two results. Changes in wages, especially of heads, were much more powerful cause of the widening income disparity when the top and bottom 10 percent families were excluded from the decomposition. Wage changes alone explain 38 percent of the rise in the measure of income inequality. On the other hand, the influence of labor supply changes was much smaller for the income inequality between the families in the second and ninth deciles. This pattern is generally true for each of the three decades, but 
more clearly observed for the 1980s during which wage changes accounted for 85 percent of the rise in the measure of income inequality.

\section{Sensitivity of the Result to the Choice of Population}

Although the population chosen above, namely families headed by working age persons, is widely used in the study of income distribution and poverty, there is no standard rule to select sample to be studied. The pattern of living arrangement and the family structure have dramatically changed over the three decades under investigation. Thus, the populations compared above between 1969 and 1999 may be different in various aspects, and a change in the population covered by the study may lead to a different conclusion. I repeat the same decomposition using several alternative samples covering different populations to examine whether the result obtained above is sensitive to the choice of population.

I begin with analyzing a broader population, namely, all households including non-family households. The proportion of non-family households increased from 19 percent in 1969 to 31 percent in 2000 (U.S. Bureau of the Census 1996, No. 66; U.S. Bureau of the Census 2004, No. 56). We thus tend to look at increasingly narrow segment of the population over time by focusing on family households. Given that nonfamily households are overrepresented in lower-income households, we may have a different result if this broader sample is used.

The first column of Table 6 presents the result. The estimated measure of the rise in the family income inequality (0.9576) and the relative size of each component's contribution to the increase in income inequality are remarkably similar to the results based on the sample of families reported in Table 2 . The only notable difference is the relatively greater contribution of the change in the employment rate for heads (13 percent) where all households are concerned.

The next issue to be addressed with regard to the choice of the sample is the age range of family heads. Although persons aged 18 to 64 are largely regarded as the working-age population, it is not fully comparable across different times for the following reasons. First, the college enrollment considerably increased between 1970 and 2000, diminishing the proportion of young family heads covered by this study 
(because the families whose heads are enrolled in school are excluded). ${ }^{16}$ Second, the typical retirement age has diminished as early retirement (defined as leaving the labor force permanently at age younger than 65) became increasingly common. ${ }^{17}$

To reduce the effect of the change in the typical working age, I restrict the sample to families headed by persons aged 25 to 55 . The result of the decomposition based on this sample is reported in the second column of Table 6. Although the results based on all families and families headed by prime-age persons are not perfectly matched, their implications are not much different from each other. Similar to the result for all families, changing labor supply explains about a third of the increase in the measure of the family inequality; wage changes account for another 31 percent. Notable differences are relatively small effect of the shift in the composition of income sources and a large impact of changing family structure.

Another prominent change in the family structure over the last several decades is the rise of the proportion of female-headed families. In 1970, less than 11 percent of families were headed by women (U.S. Bureau of the Census 1996, No. 66); now, 18 percent of families are female-headed (U.S. Bureau of the Census 2004, No. 60). Moreover, the growth of female-headed families was particularly pronounced among low-income families. In consequence, female-headed families currently account for more than half of the lowest $10^{\text {th }}$ families.

To eliminate the effects of changes in the working age and family structure introduced above, I decompose the rise in the family income inequality using the sample of families headed by males aged 25 to 55 (See column 3 of Table 6). The magnitude of the increase the measure of income inequality between 1969 and 1999 for this sample $(0.6485)$ is slightly greater than half of the estimate obtained from the sample of families headed by prime-age persons (1.2390), and about two thirds of the estimate for all families headed by working age persons (0.9600). This result indicates that growing instability of the family is a major factor of the rising family income inequality. The relative contribution of each of the components of family income is also

\footnotetext{
${ }^{16}$ The school enrollment rate for persons aged 18 to 19 increased from 47.7 percent in 1970 to 61.2 percent in 2000 . The same rates for individuals aged 22 to 24 increased from 14.9 percent to 24.6 percent during the three decades (U.S. Bureau of the Census 2004, No. 206).

${ }^{17}$ The labor force participation rate of men aged 55 to 64 declined from 73 percent in 1980 to 67 percent in 2000 (U.S. Bureau of the Census 2004, No. 570).
} 
quite different. In particular, wage changes were the most powerful factor of the increase in the income inequality among the families headed by prime-age males. However, similar to the results for the full sample, labor supply changes explain 31 percent of the rise in the measure of income inequality.

\section{Conclusions}

This study has estimated what fraction of the rise in family income inequality in the United States between 1968 and 2000 is accounted for by change in each of the family income components such as wages, employment, and hours worked of family heads and spouses, family structure, and other incomes. The increased disparity in other incomes $(Q)$ accounts for 29 percent of the rise in the difference in income between the top $10^{\text {th }}$ and bottom $10^{\text {th }}$ families. Changes in employment and hours worked explain 28 percent of the rise in the family income inequality between 1969 and 1999. More specifically, changes in the hours worked and the employment rate of heads explain, respectively, 13 percent and 9 percent of the increase in the income disparity, and change in the employment rate of spouses accounts for another 7 percent. Structural changes in wages, largely regarded as the major culprit of the increase in income inequality, explain less than a quarter of the rise in the measure of family income inequality. Changing fraction of families with both husband and wife accounts for 11 percent of the widening of the income gap between the top and bottom income deciles. Changes in the composition of the income sources explain the remaining 16 percent of the rise in the measure of inequality.

The relative contribution of each of the components of family income considerably differed by decade. In particular, the relative importance of the effect of changing labor supply, especially that of the employment rate for heads, declined over time. On the other hand, a much greater percentage of the rise in family income inequality during the 1990 s is explained by changing wages compared to the previous two decades.

The sharp rise of the family income inequality was largely due to the collapse of low-income families. About 70 percent of the increase in the income difference between the top and bottom $10^{\text {th }}$ families were produced by deterioration of the position of the poorest $10^{\text {th }}$ relative to the average household. For the upper half of the income 
distribution, wage changes were the dominant causes of the increase in the measure of family income inequality. For the lower half of the income distribution, in sharp contrast, changes in labor supply and other incomes were the principal causes of the growing distance between the poor and middle-income families.

If the families in the second and ninth income deciles are compared, changes in wages, especially of heads, were much more powerful cause of the widening income disparity. The results of decompositions based on alternative samples (all households including families and single householders, families headed by prime-age persons, and families headed by prime-age males), though considerably different from one another, provide generally similar implications. It is especially notable that changing labor supply explains about a third of the rise in the measure of family income inequality between 1969 and 1999 (28 percent to 36 percent), no matter which sample is chosen.

The most striking result of this study is that wage changes of heads and spouses explain only a modest fraction of the widening of the income gap between the top and bottom $10^{\text {th }}$ families. Prior to the 1990 s, in particular, less than 10 percent of the rise in the measure of family income inequality resulted from wage changes. On the other hand, changing employment and hours exerted stronger impacts on the increase in family income inequality than previously thought. The influence of changing labor supply was particularly powerful prior to 1990, accounting for 63 percent and 33 percent of the rise in measure of family income inequality during the 1970s and 1980s, respectively. In particular, the relative decline in the employment rate and hours worked among poor householders were the single most important cause of the collapse of the families at the bottom of income distribution between 1969 and 1989.

Along with changing employment and hours of work, the relative decline in other incomes of low-income families was an important cause of the rise in the disparity in family income. Since other incomes of the lowest $10^{\text {th }}$ families are largely composed of transfer incomes, relative decline of their other incomes may have been in part produced by changes in government income distribution policy. It may also be partly attributable to the rise in capital incomes of middle- and high-income families since the mid-1970s. ${ }^{18}$

${ }^{18}$ The capital income share in the U.S. personal income increased from around 13 percent in the 
Another interesting result is that the 1990s was distinct from the previous two decades in terms of the magnitude and the mechanisms of rise in family income inequality. The rise in the measure of family income inequality during the 1990s was more than twice as large as those of the previous two decades combined. In contrast to the 1970s and 1980s during which the rise in family income inequality was largely produced by the relative decline of bottom $10^{\text {th }}$ families, about two thirds of the increase in family income inequality during the 1990s resulted from the faster income growth of the richest $10^{\text {th }}$ families compared to entire families. Wage changes were a much more important factor of the rise in family income inequality for the 1990s than for the previous two decades. These peculiar features of the 1990s may be explained by the dramatic increase in the wages of top 10 percent salary earners since the mid-1990s (Piketty and Saez 2001).

The results of this study suggest that the rise in the income disparity between rich and poor families over the last three decades can not simply be explained by growing wage inequality that has been highlighted. The relative declines of employment, hours, and non-labor incomes of the families at the bottom were more important factors of rising family income inequality, especially prior to 1990. Rise in the number of single-parent families was another non-trivial factor. Given that changes in employment, hours, non-labor income, and family structure had particularly strong impacts on the relative decline of the families at the bottom, these factors should be considered more seriously than wage changes in addressing poverty issues that could be more crucial for the wellbeing of the people than inequality per se.

early 1970s to 20 percent in 1990 (Piketty and Saez 2001). 


\section{References}

Autor, D., Katz, L, F., and Krueger, A, B. (1988), "Computing Inequality: Have Computers Changed The Labor Market?” Quarterly Journal of Economics, 1988, 1169-1214.

Berman, E., Bound, J., and Griliches, Z. (1994), "Changes in the Demand for Skilled Labor within U. S. Manufacturing: Evidence from the Annual Survey of Manufactures," Quarterly Journal of Economics 109(2), 367-397.

Blank, Rebecca M. (1997), It Takes A Nation: A New Agenda for Fighting Poverty, Princeton University Press.

Boisjoly, J., G. Duncan, and T. Smeeding, "The Shifting Incidence of Involuntary Job Losses from 1968 to 1992," Industrial Relations 37, 1998, 207-31.

Borjas, G, J., Freeman, R, B., and Katz, L, F. (1997), "How Much Do Immigration and Trade Affect Labor Market Outcomes?" Brookings Papers on Economic Activity 1.

(1992), "On The Labor-Market Effects of

Immigration and Trade,"in Borjas, G, J., and Freeman, R, B., eds, Immigration and The Work Force, Chicago University Press.

Bound, J., and Johnson, G. (1992), "Change in The Structure of Wages in the 1980s: An Evaluation of Alternative Explanations," American Economic Review 82

Brensnahan, T, F., Brynjolfsson, E., and Hitt, L, M. (2002), "Information Technology, Wokrplace Organization, and The Demand for Skilled Labor: Firm-Level Evidence," Quarterly Journal of Economics, 339-376.

Burtless, G. (1990), "Earnings Inequality over the Business and Demographic Cycles," in Burtless, G., ed., A Future of Lousy Jobs? The Changing Structure of U. S. Wages. Washington DC: Brookings Institution, 77-117.

(1993), "The Contribution of Employment and Hours Changes to Family Income Inequality," American Economic Review Papers and Proceedings, 83, 131-135.

Cancian, M., Danziger, S., and Gottschalk, P. (1993), "Working Wives and Family Income Inequality Among Married Couples," in Danziger and Gottschalk, eds., Uneven Tides. New York: Russell Sage Foundation, 195-221.

Doms, M., Dunne, T., and Troske, K, R. (1997), "Workers, Wages, and Technology," Quarterly Journal of Economics 112, 253-290.

Feenstra, R, C., and Hanson, G, H. (1999), "The Impact of Outsourcing and HighTechnology Capital on Wages: Estimates for the United States, 1979-90," Quarterly Journal of Economics 114.

Freeman, R, B., and L. F. Katz, eds (1995), Differences and Changes in Wage Structures, Chicago: University of Chicago Press, 1995. 
Fortin, N, M., and Lemieux, T. (1997), "Institutional Changes and Rising Wage Inequality: Is There A Linkage?” Journal of Economic Perspectives 11, 75-96.

Gottschalk, P. (1997), "Inequality, Income Growth, and Mobility: The Basic Facts," Journal of Economic Perspectives 11, 21-40.

Gottschalk, P., and R. Moffitt (1999), "Changes in Job Instability and Insecurity Using Monthly Survey Data," Journal of Labor Economics 17, 1999, S92-S126.

Gottschalk, P., and Smeeding, T. M. (1997), "Cross-National Comparisons of Earnings and Income Inquality," Journal of Economic Literature 35.

Haveman, R. (1996), Earnings Inequality: The Influence of Changing Opportunities and Choices. Washington DC: The AEI Press.

Hunt, J. (1992), "The Impact of the 1962 Repatriates from Algeria on the French Labor Market," Industrial and Labor Relations Review, 45, 1992, 556-572.

Hyslop, Dean R. (2001), "Rising U.S. Earnings Inequality and Family Labor Supply: The Covariance Structure of Intrafamily Earnings, American Economic Review 91, No. 4, 755-777.

Juhn, C. (1997), "Decline of Male Labor Market Participation: The Role of Declining Market Opportunities," Quarterly Journal of Economics 107, 1992, 79-121.

Juhn, C., and K. M. Murphy (1997), "Wage Inequality and Family Labor Supply,” Journal of Labor Economics 15, 72-97.

Katz, L, F., and K. M. Murphy (1992), "Changes in Relative Wages, 1963-1987: Supply and Demand Factors," Quarterly Journal of Economics 107, 35-78.

Krueger, A, B. (1993), "How Computers Have Changed The Wage Structure: Evidence From Microdata, 1984-90," Quarterly Journal of Economics 108, 33-60.

Lee, C. (2001), "Changes in Employment and Hours, and Family Income Inequality in the United States, 1969-1989," International Economic Journal 15, 27-49.

Levy, F., and R. J. Murane (1992), "U. S. Earnings Levels and Earnings Inequality: A Review of Recent Trends and Proposed Explanations," Journal of Economic Literature 30.

Miller, T, C. (2001), "Impact of Globalization on U. S. Wage Inequality: Implications for Policy," North American Journal of Economics and Finance 12, 219-242.

Mofitt, R. (1990), "The Distribution of Earnings and the Welfare States," in Burtless, G., ed., A Future of Lousy Jobs? The Changing Structure of U. S. Wages, Washington DC: Brookings Institution, 201-230.

(1995), Current Population Surveys: March Indivisual -Level Extracts, 1968-1992, Inter-university Consortium for Political and Social Research, 6171.

OECD (1996), "Earnings Inequality, Low-Paid Employment and Earnings Mobility," Employment Outlook, July, 59-108. 
Piketty, Thomas, and Emmanuel Saez (2001), "Income Inequality in the United States, 19131998," National Bureau of Economic Research Working Paper No. 8467.

Sachs, J, D., and H. J. Shatz (1994), “Trade and Jobs in U.S. Manufacturing,” Brookings Papers on Economic Activity 1.

United States Bureau of the Census (1996), Statistical Abstract of the United States, Washington DC: GPO.

Washington DC: GPO.

(2004), Statistical Abstract of the United States,

Wood, A. (1994), North-South Trade, Employment, and Inequality: Changing Fortunes in a Skill-Driven World. Oxford: Clarendon Press. 
Table 1

Definition of Variables Used

\begin{tabular}{|c|l|}
\hline Variable & \multicolumn{1}{|c|}{ Definition of Variable } \\
\hline$H_{h}$ & Average monthly money income of households in a given income decile \\
$H_{s}$ & Mean monthly hours worked by employed spouse \\
$W_{h}$ & Mean hourly wage rate of employed head of household \\
$W_{s}$ & Mean hourly wage rate of employed spouse \\
$P_{h}$ & Employment rate for heads of households \\
$P_{s}$ & Employment rate for spouses \\
$\delta$ & The fraction of households in which both husband and wife are present \\
$Q$ & The mean annual income from other sources \\
$*$ & The difference in the log of an income variable between two the top and the \\
& bottom income deciles; e.g., $H_{h}^{*}=\ln \left(H_{h}^{T O P}\right)-\ln \left(H_{h}^{\text {BOTTOM }}\right)$ \\
$\Phi_{h}$ & The weight of the income earned by the head of household \\
$\Phi_{s}$ & The weight of the income earned by spouse \\
$\Phi_{Q}$ & The weight of the income from other sources \\
\hline
\end{tabular}


Table 2

A Decomposition of the Change in Family Income Inequality, 1969-2000: Difference in Income between the Top and Bottom Deciles

\begin{tabular}{|c|c|c|c|c|c|c|c|c|}
\hline \multirow[b]{2}{*}{ Variable } & \multicolumn{2}{|c|}{ 1969-1979 } & \multicolumn{2}{|c|}{ 1979-1989 } & \multicolumn{2}{|c|}{ 1989-1999 } & \multicolumn{2}{|c|}{ 1969-1999 } \\
\hline & Estimate & Share & Estimate & Share & Estimate & Share & Estimate & Share \\
\hline (1) $\Delta N^{*}$ & 0.2156 & 1.0000 & 0.2089 & 1.0000 & 0.5355 & 1.0000 & 0.9600 & 1.0000 \\
\hline (2) $\Phi_{h} \Delta H_{h}^{*}$ & 0.0487 & 0.2035 & 0.0347 & 0.1659 & 0.0395 & 0.0738 & 0.1233 & 0.1282 \\
\hline (3) $\Phi_{h} \Delta W_{h}^{*}$ & 0.0277 & 0.1284 & -0.0243 & -0.1162 & 0.1010 & 0.1885 & 0.1107 & 0.1153 \\
\hline (4) $\Phi_{h} \Delta P_{h}^{*}$ & 0.0711 & 0.3300 & 0.0305 & 0.1822 & -0.0187 & -0.0350 & 0.0846 & 0.0881 \\
\hline (5) $\Delta \Phi_{h}\left(H_{h}^{*}+W_{h}^{*}\right)$ & -0.2043 & -0.8135 & -0.0504 & -0.2013 & 0.0179 & 0.0280 & -0.2416 & -0.2160 \\
\hline (6) $\Phi_{s} \Delta H_{s}^{*}$ & 0.0007 & 0.0032 & -0.0043 & -0.0204 & -0.0061 & -0.0114 & -0.0085 & -0.0089 \\
\hline (7) $\Phi_{s} \Delta W_{s}^{*}$ & -0.0064 & -0.0297 & 0.0322 & 0.1542 & 0.1065 & 0.1989 & 0.1115 & 0.1161 \\
\hline (8) $\Phi_{s} \Delta P_{s}^{*}$ & 0.0193 & 0.0897 & 0.0008 & 0.0038 & 0.0459 & 0.0857 & 0.0654 & 0.0682 \\
\hline (9) $\Phi_{s} \Delta \delta^{*}$ & 0.0229 & 0.1062 & -0.0015 & -0.0072 & 0.0910 & 0.1700 & 0.1046 & 0.1090 \\
\hline (10) $\Delta \Phi_{s}\left(H_{s}^{*}+W_{s}^{*}+P_{s}^{*}+\delta^{*}\right)$ & 0.0655 & 0.3067 & 0.1758 & 0.8418 & 0.1633 & 0.3049 & 0.4326 & 0.4506 \\
\hline (11) $\Phi_{q} \Delta Q^{*}$ & 0.1025 & 0.4753 & 0.0741 & 0.3550 & 0.1159 & 0.2165 & 0.2740 & 0.2854 \\
\hline (12) $\Delta \Phi_{q} Q^{*}$ & 0.0771 & 0.3578 & -0.0663 & -0.3172 & -0.0962 & -0.1797 & -0.0670 & -0.0698 \\
\hline (13) $\varepsilon$ & -0.0044 & -0.0203 & -0.0001 & -0.0004 & -0.0024 & -0.0456 & -0.0295 & -0.0307 \\
\hline Labor Supply: (2)+(4)+(6)+(8) & 0.1304 & 0.6265 & 0.0693 & 0.3315 & 0.0606 & 0.1131 & 0.2648 & 0.2758 \\
\hline Wage: $(3)+(7)$ & 0.0213 & 0.0988 & 0.0079 & 0.0380 & 0.2074 & 0.3874 & 0.2221 & 0.2314 \\
\hline Composition: $(5)+(10)+(12)$ & -0.0618 & -0.2865 & 0.0591 & -0.2831 & 0.0850 & 0.1587 & 0.1239 & 0.1291 \\
\hline
\end{tabular}

Sources: Computed based on CPS data for 1968, 1969, 1970, 1978, 1979, 1980, 1988, 1989, 1990, 1998, 1999 , and 2000.

Notes: See text for the methods of computation. "Share" provides the percentage of the increase in the measure of family income inequality explained by the variable. 
Table 3

A Decomposition of the Change in Family Income Inequality:

Difference between the Income of the Top Decile and the Average Income

\begin{tabular}{|c|c|c|c|c|c|c|c|c|}
\hline \multirow[b]{2}{*}{ Variable } & \multicolumn{2}{|c|}{ 1969-1979 } & \multicolumn{2}{|c|}{ 1979-1989 } & \multicolumn{2}{|c|}{ 1989-1999 } & \multicolumn{2}{|c|}{ 1969-1999 } \\
\hline & Estimate & Share & Estimate & Share & Estimate & Share & Estimate & Share \\
\hline (1) $\Delta N^{*}$ & -0.0149 & 1.0000 & 0.0710 & 1.0000 & 0.1985 & 1.0000 & 0.2546 & 1.0000 \\
\hline (2) $\Phi_{h} \Delta H_{h}^{*}$ & 0.0066 & -0.4486 & 0.0035 & 0.0487 & -0.0008 & -0.0039 & 0.0087 & 0.0341 \\
\hline (3) $\Phi_{h} \Delta W_{h}^{*}$ & -0.0439 & 2.9495 & 0.0442 & 0.6227 & 0.1140 & 0.5740 & 0.1304 & 0.5121 \\
\hline (4) $\Phi_{h} \Delta P_{h}^{*}$ & 0.0200 & -1.3443 & 0.0036 & 0.0504 & -0.0009 & -0.0047 & 0.0209 & 0.0819 \\
\hline (5) $\Delta \Phi_{h}\left(H_{h}^{*}+W_{h}^{*}\right)$ & -0.0562 & 3.4423 & -0.0430 & -0.5420 & -0.0655 & -0.2996 & -0.1784 & -0.6469 \\
\hline (6) $\Phi_{s} \Delta H_{s}^{*}$ & -0.0090 & 0.6025 & -0.0054 & -0.0766 & -0.0049 & -0.0249 & -0.0242 & -0.0950 \\
\hline (7) $\Phi_{s} \Delta W_{s}^{*}$ & 0.0021 & -0.1428 & 0.0234 & 0.3302 & 0.0505 & 0.2546 & 0.0716 & 0.2811 \\
\hline (8) $\Phi_{s} \Delta P_{s}^{*}$ & -0.0018 & 0.1241 & 0.0042 & 0.0594 & 0.0020 & 0.0100 & 0.0036 & 0.0142 \\
\hline (9) $\Phi_{s} \Delta \delta^{*}$ & 0.0058 & -0.3900 & -0.0040 & -0.0570 & 0.0394 & 0.1987 & 0.0366 & 0.1437 \\
\hline (10) $\Delta \Phi_{s}\left(H_{s}^{*}+W_{s}^{*}+P_{s}^{*}+\delta^{*}\right)$ & 0.0273 & -1.8356 & 0.0552 & 0.7770 & 0.0966 & 0.4867 & 0.1939 & 0.7614 \\
\hline (11) $\Phi_{q} \Delta Q^{*}$ & 0.0002 & -0.0105 & 0.0060 & 0.0852 & -0.0030 & -0.0151 & 0.0024 & 0.0094 \\
\hline (12) $\Delta \Phi_{q} Q^{*}$ & 0.0340 & -2.2826 & -0.0167 & -0.2346 & -0.0289 & -0.1456 & -0.0108 & -0.0423 \\
\hline (13) $\varepsilon$ & -0.0000 & 0.0017 & 0.0000 & 0.0006 & 0.0001 & 0.0001 & 0.0000 & 0.0002 \\
\hline Labor Supply: (2)+(4)+(6)+(8) & 0.0158 & -1.0625 & 0.0058 & 0.0820 & -0.0046 & -0.0234 & 0.0089 & 0.0351 \\
\hline Wage: (3)+(7) & -0.0418 & 2.8067 & 0.0677 & 0.9529 & 0.1645 & 0.8286 & 0.2019 & 0.7931 \\
\hline Composition: $(5)+(10)+(12)$ & 0.0051 & -0.3455 & -0.0045 & -0.0637 & 0.0022 & 0.0110 & 0.0047 & 0.0185 \\
\hline
\end{tabular}

Sources: Computed based on CPS data for 1968, 1969, 1970, 1978, 1979, 1980, 1988, 1989, 1990, 1998, 1999 , and 2000.

Notes: See text for the methods of computation. "Share" provides the percentage of the increase in the measure of family income inequality explained by the variable. 
Table 4

A Decomposition of the Change in Family Income Inequality:

Difference between the Average Income and the Income of the Bottom Decile

\begin{tabular}{|c|c|c|c|c|c|c|c|c|}
\hline \multirow[b]{2}{*}{ Variable } & \multicolumn{2}{|c|}{ 1969-1979 } & \multicolumn{2}{|c|}{ 1979-1989 } & \multicolumn{2}{|c|}{ 1989-1999 } & \multicolumn{2}{|c|}{ 1969-1999 } \\
\hline & Estimate & Share & Estimate & Share & Estimate & Share & Estimate & Share \\
\hline (1) $\Delta N^{*}$ & 0.2304 & 1.0000 & 0.1379 & 1.0000 & 0.3370 & 1.0000 & 0.7053 & 1.0000 \\
\hline (2) $\Phi_{h} \Delta H_{h}^{*}$ & 0.0393 & 0.1704 & 0.0324 & 0.2352 & 0.0407 & 0.1206 & 0.1172 & 0.1661 \\
\hline (3) $\Phi_{h} \Delta W_{h}^{*}$ & 0.0642 & 0.2788 & -0.0614 & -0.4452 & -0.0005 & -0.0015 & -0.0029 & -0.0041 \\
\hline (4) $\Phi_{h} \Delta P_{h}^{*}$ & 0.0561 & 0.2433 & 0.0358 & 0.2596 & -0.0181 & -0.0537 & 0.0672 & 0.0953 \\
\hline (5) $\Delta \Phi_{h}\left(H_{h}^{*}+W_{h}^{*}\right)$ & -0.1422 & -0.5168 & -0.0481 & -0.2826 & 0.0073 & 0.0174 & -0.1775 & -0.2088 \\
\hline (6) $\Phi_{s} \Delta H_{s}^{*}$ & 0.0077 & 0.0333 & -0.0003 & -0.0021 & -0.0027 & -0.0080 & 0.0077 & 0.0110 \\
\hline (7) $\Phi_{s} \Delta W_{s}^{*}$ & -0.0083 & -0.0361 & 0.0155 & 0.1126 & 0.0705 & 0.2093 & 0.0612 & 0.0867 \\
\hline (8) $\Phi_{s} \Delta P_{s}^{*}$ & 0.0216 & 0.0938 & -0.0024 & -0.0174 & 0.0437 & 0.1298 & 0.0614 & 0.0870 \\
\hline (9) $\Phi_{s} \Delta \delta^{*}$ & 0.0194 & 0.0842 & 0.0015 & 0.0111 & 0.0628 & 0.1864 & 0.0777 & 0.1102 \\
\hline (10) $\Delta \Phi_{s}\left(H_{s}^{*}+W_{s}^{*}+P_{s}^{*}+\delta^{*}\right)$ & 0.0525 & 0.2277 & 0.1324 & 0.9606 & 0.0701 & 0.2080 & 0.2761 & 0.3915 \\
\hline (11) $\Phi_{q} \Delta Q^{*}$ & 0.0979 & 0.4249 & 0.0606 & 0.4392 & 0.1206 & 0.3578 & 0.2671 & 0.3786 \\
\hline (12) $\Delta \Phi_{q} Q^{*}$ & 0.0264 & 0.1147 & -0.0254 & -0.1846 & -0.0285 & -0.0847 & -0.0133 & -0.0188 \\
\hline (13) $\varepsilon$ & -0.0041 & -0.0177 & -0.0028 & -0.0205 & -0.0288 & -0.0855 & -0.0366 & -0.0518 \\
\hline Labor Supply: (2)+(4)+(6)+(8) & 0.1246 & 0.5407 & 0.0655 & 0.4753 & 0.0636 & 0.1887 & 0.2535 & 0.3595 \\
\hline Wage: $(3)+(7)$ & 0.0559 & 0.2427 & -0.0459 & -0.3326 & -0.0700 & 0.2078 & 0.0583 & 0.0826 \\
\hline Composition: $(5)+(10)+(12)$ & -0.0633 & -0.2746 & 0.0589 & 0.4275 & 0.0488 & 0.1448 & 0.0853 & 0.1209 \\
\hline
\end{tabular}

Sources: Computed based on CPS data for 1968, 1969, 1970, 1978, 1979, 1980, 1988, 1989, 1990, 1998, 1999 , and 2000.

Notes: See text for the methods of computation. "Share" provides the percentage of the increase in the measure of family income inequality explained by the variable. 
Table 5

A Decomposition of the Change in Family Income Inequality:

Difference in Income between the Second and Ninth Income Deciles

\begin{tabular}{|c|c|c|c|c|c|c|c|c|}
\hline \multirow[b]{2}{*}{ Variable } & \multicolumn{2}{|c|}{ 1969-1979 } & \multicolumn{2}{|c|}{ 1979-1989 } & \multicolumn{2}{|c|}{ 1989-1999 } & \multicolumn{2}{|c|}{ 1969-1999 } \\
\hline & Estimate & Share & Estimate & Share & Estimate & Share & Estimate & Share \\
\hline (1) $\Delta N^{*}$ & 0.1768 & 1.0000 & 0.1318 & 1.0000 & 0.2393 & 1.0000 & 0.5477 & 1.0000 \\
\hline (2) $\Phi_{h} \Delta H_{h}^{*}$ & 0.0260 & 0.1473 & 0.0009 & 0.0070 & 0.0097 & 0.0407 & 0.0362 & 0.0661 \\
\hline (3) $\Phi_{h} \Delta W_{h}^{*}$ & 0.0601 & 0.3400 & 0.0732 & 0.5557 & 0.0042 & 0.0175 & 0.1366 & 0.2495 \\
\hline (4) $\Phi_{h} \Delta P_{h}^{*}$ & 0.0387 & 0.2190 & -0.0050 & -0.0378 & 0.0107 & 0.0445 & 0.0431 & 0.0787 \\
\hline (5) $\Delta \Phi_{h}\left(H_{h}^{*}+W_{h}^{*}\right)$ & -0.0708 & -0.3519 & -0.0733 & -0.4863 & -0.0322 & -0.1180 & -0.1737 & -0.2796 \\
\hline (6) $\Phi_{s} \Delta H_{s}^{*}$ & -0.0115 & -0.0649 & -0.0138 & -0.1050 & -0.0266 & -0.1110 & -0.0513 & -0.0936 \\
\hline (7) $\Phi_{s} \Delta W_{s}^{*}$ & 0.0046 & 0.0262 & 0.0391 & 0.2969 & 0.0302 & 0.1262 & 0.0711 & 0.1299 \\
\hline (8) $\Phi_{s} \Delta P_{s}^{*}$ & 0.0130 & 0.0738 & -0.0122 & -0.0928 & 0.0246 & 0.1030 & 0.0350 & 0.0456 \\
\hline (9) $\Phi_{s} \Delta \delta^{*}$ & 0.0131 & 0.0741 & -0.0145 & -0.1099 & 0.1037 & 0.4333 & 0.0874 & 0.1596 \\
\hline (10) $\Delta \Phi_{s}\left(H_{s}^{*}+W_{s}^{*}+P_{s}^{*}+\delta^{*}\right)$ & 0.0428 & 0.2421 & 0.1215 & 0.9218 & 0.0748 & 0.3125 & 0.2566 & 0.4684 \\
\hline (11) $\Phi_{q} \Delta Q^{*}$ & 0.0378 & 0.2139 & 0.0258 & 0.1957 & 0.0630 & 0.2638 & 0.1196 & 0.2184 \\
\hline (12) $\Delta \Phi_{q} Q^{*}$ & 0.0222 & 0.1256 & -0.0111 & -0.0840 & -0.0137 & -0.0572 & 0.0044 & 0.0080 \\
\hline (13) $\varepsilon$ & 0.0006 & 0.0035 & 0.0012 & 0.0088 & -0.0092 & -0.0383 & -0.0074 & -0.0135 \\
\hline Labor Supply: (2)+(4)+(6)+(8) & 0.0663 & 0.3751 & -0.0301 & -0.2285 & -0.0058 & 0.0772 & 0.0530 & 0.0968 \\
\hline Wage: $(3)+(7)$ & 0.0647 & 0.3662 & 0.1123 & 0.8526 & 0.0371 & 0.1437 & 0.2078 & 0.3793 \\
\hline Composition: $(5)+(10)+(12)$ & -0.0058 & -0.0328 & 0.0371 & 0.2814 & 0.0289 & 0.1208 & 0.0873 & 0.1593 \\
\hline
\end{tabular}

Sources: Computed based on CPS data for 1968, 1969, 1970, 1978, 1979, 1980, 1988, 1989, 1990, 1998, 1999 , and 2000.

Notes: See text for the methods of computation. "Share" provides the percentage of the increase in the measure of family income inequality explained by the variable. 
Table 6

A Decomposition of the Change in the Gap between the Top and Bottom Income Deciles, 1969-1999:

Results based on Alternative Samples

\begin{tabular}{|c|c|c|c|c|c|c|}
\hline \multirow[t]{2}{*}{ Variable } & \multicolumn{2}{|c|}{$\begin{array}{c}\text { (1) } \\
\text { Families and single householders }\end{array}$} & \multicolumn{2}{|c|}{$\begin{array}{c}\text { (2) } \\
\text { Families headed by persons } \\
\text { ages } 25 \text { to } 55\end{array}$} & \multicolumn{2}{|c|}{$\begin{array}{c}(3) \\
\text { Families headed by males } \\
\text { ages } 25 \text { to } 55\end{array}$} \\
\hline & Estimate & Share & Estimate & Share & Estimate & Share \\
\hline (1) $\Delta N^{*}$ & 0.9576 & 1.0000 & 1.2390 & 1.0000 & 0.6485 & 1.0000 \\
\hline (2) $\Phi_{h} \Delta H_{h}^{*}$ & 0.1170 & 0.1222 & 0.1862 & 0.1503 & 0.0645 & 0.0994 \\
\hline (4) $\Phi_{h} \Delta P_{h}^{*}$ & 0.1435 & 0.1498 & 0.2404 & 0.1940 & 0.2173 & 0.3350 \\
\hline (4) $\Phi_{h} \Delta W_{h}^{*}$ & 0.1276 & 0.1332 & 0.2001 & 0.1615 & 0.0849 & 0.1310 \\
\hline (5) $\Delta \Phi_{h}\left(H_{h}^{*}+W_{h}^{*}\right)$ & -0.2977 & -0.2620 & -0.3416 & -0.2453 & -0.0628 & -0.0890 \\
\hline (6) $\Phi_{s} \Delta H_{s}^{*}$ & -0.0061 & -0.0064 & -0.0055 & -0.0044 & -0.0044 & -0.0068 \\
\hline (7) $\Phi_{s} \Delta W_{s}^{*}$ & 0.1252 & 0.1307 & 0.1468 & 0.1185 & 0.0483 & 0.0744 \\
\hline (8) $\Phi_{s} \Delta P_{s}^{*}$ & 0.0638 & 0.0666 & 0.0643 & 0.0519 & 0.0581 & 0.0896 \\
\hline (9) $\Phi_{s} \Delta \delta^{*}$ & 0.1065 & 0.1112 & 0.1970 & 0.1590 & 0.0393 & 0.0606 \\
\hline (10) $\Delta \Phi_{s}\left(H_{s}^{*}+W_{s}^{*}+P_{s}^{*}+\delta^{*}\right)$ & 0.4491 & 0.4689 & 0.3732 & 0.3012 & 0.1730 & 0.2668 \\
\hline (11) $\Phi_{q} \Delta Q^{*}$ & 0.2536 & 0.2645 & 0.1654 & 0.1335 & 0.1076 & 0.1659 \\
\hline (12) $\Delta \Phi_{q} Q^{*}$ & -0.0068 & -0.0071 & 0.0316 & 0.0255 & -0.0767 & -0.1183 \\
\hline (13) $\varepsilon$ & -0.1176 & -0.1228 & -0.0188 & -0.0151 & -0.0004 & -0.0007 \\
\hline Labor Supply: $(2)+(4)+(6)+(8)$ & 0.3022 & 0.3156 & 0.4451 & 0.3593 & 0.2031 & 0.3132 \\
\hline Wage: (3)+(7) & 0.2686 & 0.2805 & 0.3870 & 0.3125 & 0.2655 & 0.4094 \\
\hline Composition: $(5)+(10)+(12)$ & 0.1446 & 0.1510 & 0.0631 & 0.0509 & 0.0335 & 0.0516 \\
\hline
\end{tabular}

Sources: Computed based on CPS data for 1968, 1969, 1970, 1998, 1999, and 2000.

Notes: See text for the methods of computation. "Share" provides the percentage of the increase in the measure of family income inequality explained by the variable. 
Appendix Table.

Components of the Average Family Income for Each Decile

\begin{tabular}{|c|c|c|c|c|c|c|c|c|c|c|c|}
\hline Year & All & Bottom & 9th & 8th & 7 th & 6th & 5 th & 4th & $3 \mathrm{rd}$ & 2nd & Top \\
\hline \multicolumn{12}{|c|}{ 1. Total Family Income } \\
\hline 1968-1970 & 30181 & 6275 & 13502 & 18078 & 21813 & 25252 & 28763 & 32818 & 37966 & 45536 & 71778 \\
\hline 1978-1980 & 32635 & 5372 & 12855 & 18087 & 22871 & 27263 & 31691 & 36615 & 42624 & 51736 & 76230 \\
\hline 1988-1990 & 34552 & 4966 & 12237 & 17900 & 22979 & 27775 & 32756 & 38422 & 45457 & 56185 & 86837 \\
\hline $1998-2000$ & 36760 & 3775 & 10260 & 15638 & 20878 & 26390 & 32225 & 38748 & 47056 & 59841 & 112770 \\
\hline \multicolumn{12}{|c|}{ 2. Annual Earnings for Employed Family Heads } \\
\hline 1968-1970 & 23034 & 4106 & 10139 & 14236 & 17583 & 20051 & 22377 & 24495 & 27328 & 31375 & 50427 \\
\hline 1978-1980 & 23376 & 3448 & 9454 & 13240 & 16559 & 20006 & 22800 & 25794 & 28821 & 33504 & 48389 \\
\hline 1988-1990 & 22889 & 3567 & 8283 & 12146 & 15500 & 18219 & 21193 & 24369 & 28155 & 33320 & 51251 \\
\hline $1998-2000$ & 22457 & 3235 & 7740 & 10890 & 13435 & 15972 & 18925 & 21811 & 25611 & 31932 & 61787 \\
\hline \multicolumn{12}{|c|}{ 3. Employment Rate for Family Heads } \\
\hline 1968-1970 & 0.929 & 0.697 & 0.859 & 0.918 & 0.946 & 0.959 & 0.968 & 0.972 & 0.976 & 0.983 & 0.984 \\
\hline 1978-1980 & 0.986 & 0.598 & 0.800 & 0.871 & 0.922 & 0.932 & 0.952 & 0.960 & 0.976 & 0.973 & 0.978 \\
\hline 1988-1990 & 0.888 & 0.552 & 0.806 & 0.871 & 0.908 & 0.932 & 0.945 & 0.956 & 0.962 & 0.972 & 0.975 \\
\hline 1998-2000 & 0.853 & 0.550 & 0.767 & 0.822 & 0.862 & 0.882 & 0.911 & 0.929 & 0.932 & 0.943 & 0.935 \\
\hline \multicolumn{12}{|c|}{ 4. Annual Hours Worked for Employed Family Heads } \\
\hline $1968-1970$ & 2187 & 1685 & 2001 & 2119 & 2159 & 2229 & 2241 & 2245 & 2287 & 2315 & 2418 \\
\hline 1978-1980 & 2117 & 1518 & 1875 & 2013 & 2094 & 2142 & 2178 & 2217 & 2230 & 2260 & 2364 \\
\hline 1988-1990 & 2121 & 1426 & 1877 & 2022 & 2109 & 2149 & 2179 & 2212 & 2238 & 2266 & 2382 \\
\hline 1998-2000 & 2033 & 1259 & 1801 & 1940 & 2000 & 2061 & 2100 & 2137 & 2171 & 2213 & 2280 \\
\hline \multicolumn{12}{|c|}{ 5. Annual Earnings for Employed Spouses } \\
\hline $1968-1970$ & 8319 & 1831 & 3393 & 4303 & 5182 & 5934 & 7198 & 8576 & 10101 & 12261 & 15653 \\
\hline 1978-1980 & 9956 & 2204 & 4050 & 5213 & 6493 & 7526 & 8800 & 10127 & 11812 & 13938 & 17871 \\
\hline
\end{tabular}




\begin{tabular}{|c|c|c|c|c|c|c|c|c|c|c|c|}
\hline 1988-1990 & 12624 & 2523 & 4582 & 6120 & 7794 & 9316 & 10787 & 12763 & 14814 & 18121 & $\begin{array}{l}24844 \\
45038\end{array}$ \\
\hline $1998-2000$ & 19394 & 2690 & 5999 & 7921 & 9926 & 11921 & 14026 & 16676 & 19691 & 24107 & 45038 \\
\hline
\end{tabular}

6. Employment Rate for Spouses

\begin{tabular}{|c|c|c|c|c|c|c|c|c|c|c|c|}
\hline 1968-1970 & 0.542 & 0.413 & 0.451 & 0.463 & 0.464 & 0.517 & 0.555 & 0.601 & 0.632 & 0.659 & 0.589 \\
\hline 1978-1980 & 0.644 & 0.405 & 0.474 & 0.563 & 0.626 & 0.636 & 0.670 & 0.700 & 0.740 & 0.760 & 0.691 \\
\hline 1988-1990 & 0.737 & 0.417 & 0.563 & 0.665 & 0.713 & 0.748 & 0.774 & 0.800 & 0.835 & 0.844 & 0.808 \\
\hline $1998-2000$ & 0.796 & 0.402 & 0.539 & 0.655 & 0.748 & 0.806 & 0.838 & 0.869 & 0.876 & 0.900 & 0.879 \\
\hline \multicolumn{12}{|c|}{ nnual Hours Worked for Employed Spouses } \\
\hline $1968-1970$ & 1441 & 1095 & 1099 & 1167 & 1221 & 1279 & 1409 & 1500 & 1597 & 1672 & 1729 \\
\hline 1978-1980 & 1454 & 1054 & 1091 & 1186 & 1325 & 1369 & 1454 & 1508 & 1599 & 1666 & 1675 \\
\hline $1988-1990$ & 1644 & 1194 & 1291 & 1410 & 1545 & 1606 & 1659 & 1718 & 1760 & 1827 & 1842 \\
\hline $1998-2000$ & 1900 & 1400 & 1600 & 1691 & 1766 & 1831 & 1886 & 1936 & 1974 & 2016 & 2091 \\
\hline \multicolumn{12}{|c|}{ oportion of Husband-Wife Families } \\
\hline $1968-1970$ & 0.884 & 0.588 & 0.783 & 0.861 & 0.910 & 0.930 & 0.938 & 0.947 & 0.952 & 0.958 & 0.967 \\
\hline $1978-1980$ & 0.852 & 0.477 & 0.714 & 0.803 & 0.873 & 0.903 & 0.925 & 0.944 & 0.954 & 0.959 & 0.970 \\
\hline $1988-1990$ & 0.868 & 0.481 & 0.774 & 0.851 & 0.890 & 0.920 & 0.931 & 0.946 & 0.954 & 0.960 & 0.968 \\
\hline $1998-2000$ & 0.739 & 0.292 & 0.479 & 0.610 & 0.707 & 0.792 & 0.838 & 0.877 & 0.910 & 0.935 & 0.951 \\
\hline \multicolumn{12}{|l|}{ mily Size } \\
\hline $1968-1970$ & 3.854 & 3.555 & 3.729 & 3.764 & 3.782 & 3.847 & 3.882 & 3.911 & 3.967 & 4.000 & 4.102 \\
\hline 1978-1980 & 3.534 & 3.388 & 3.418 & 3.419 & 3.469 & 3.495 & 3.518 & 3.544 & 3.589 & 3.671 & 3.823 \\
\hline $1988-1990$ & 3.435 & 3.360 & 3.420 & 3.414 & 3.406 & 3.415 & 3.446 & 3.445 & 3.448 & 3.467 & 3.523 \\
\hline $1998-2000$ & 3.275 & 2.973 & 3.135 & 3.191 & 3.278 & 3.320 & 3.315 & 3.343 & 3.366 & 3.415 & 3.418 \\
\hline
\end{tabular}

Sources: Computed based on CPS data for 1968, 1969, 1970, 1978, 1979, 1980, 1988, 1989, 1990, 1998, 1999, and 2000. 


\section{Figure 1}

Average Total Family Income (1982-84 dollars)

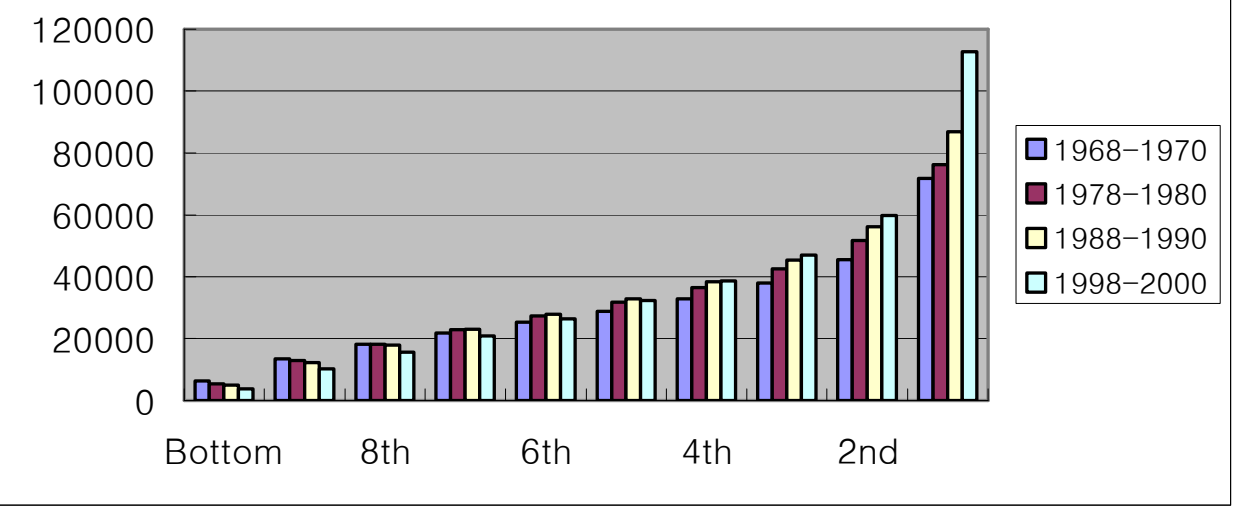

Figure 2

Average Hourly Wage for Employed Heads

(1982-84 dollar)

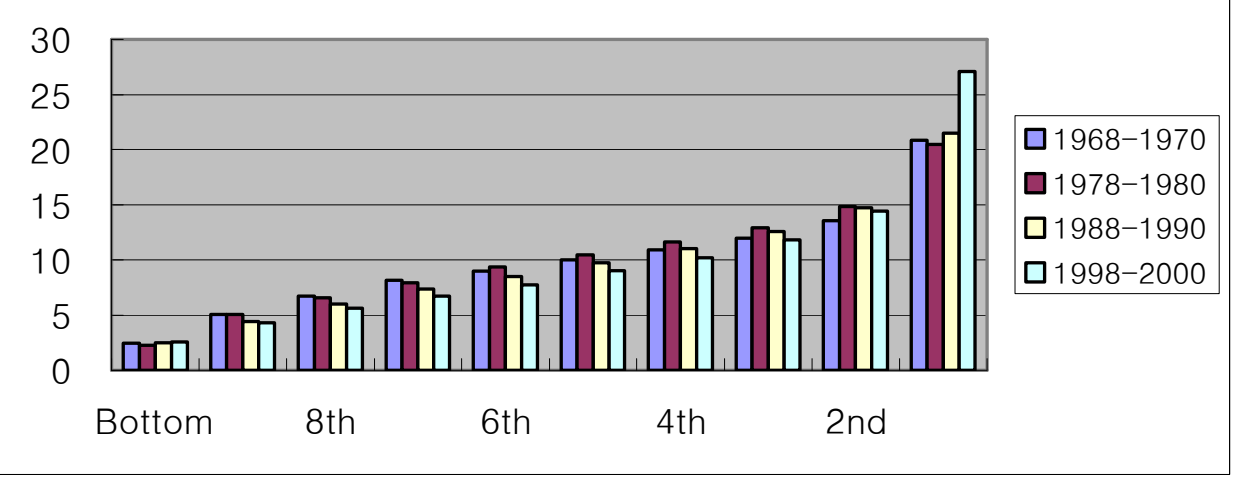

Figure 3

Proportion of Employed Heads

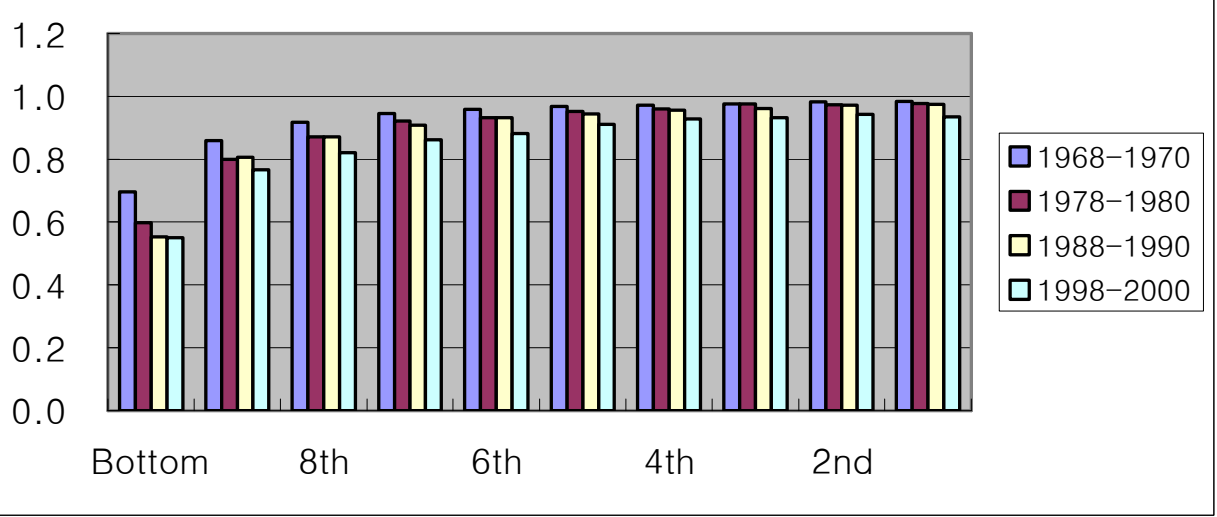


Figure 4

Annual Hours Worked for Employed Heads

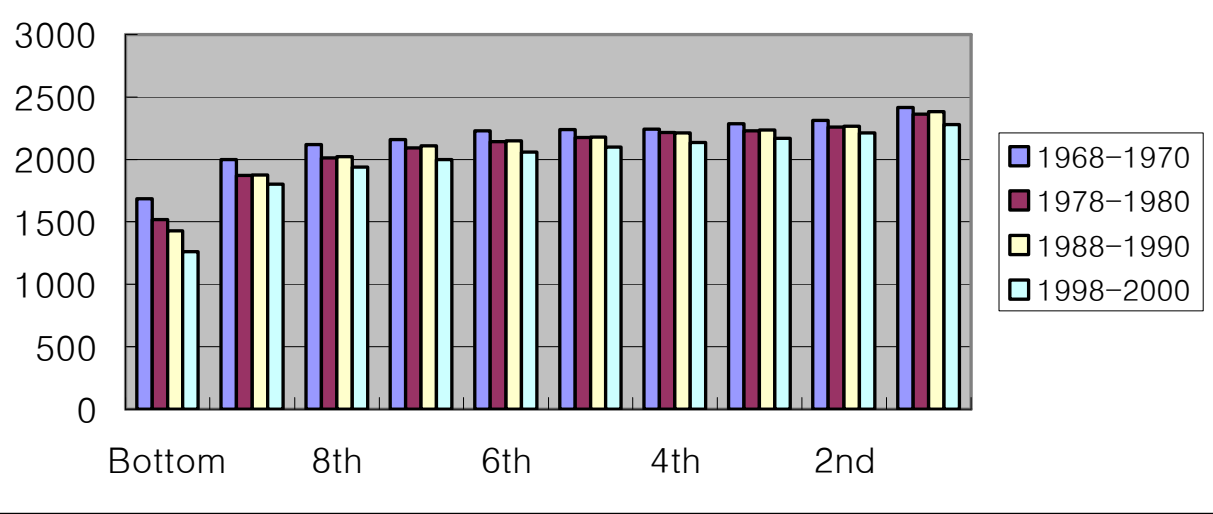

Figure 5

Average Hourly Wage for Employed Spouses

(1982-84 dollars)

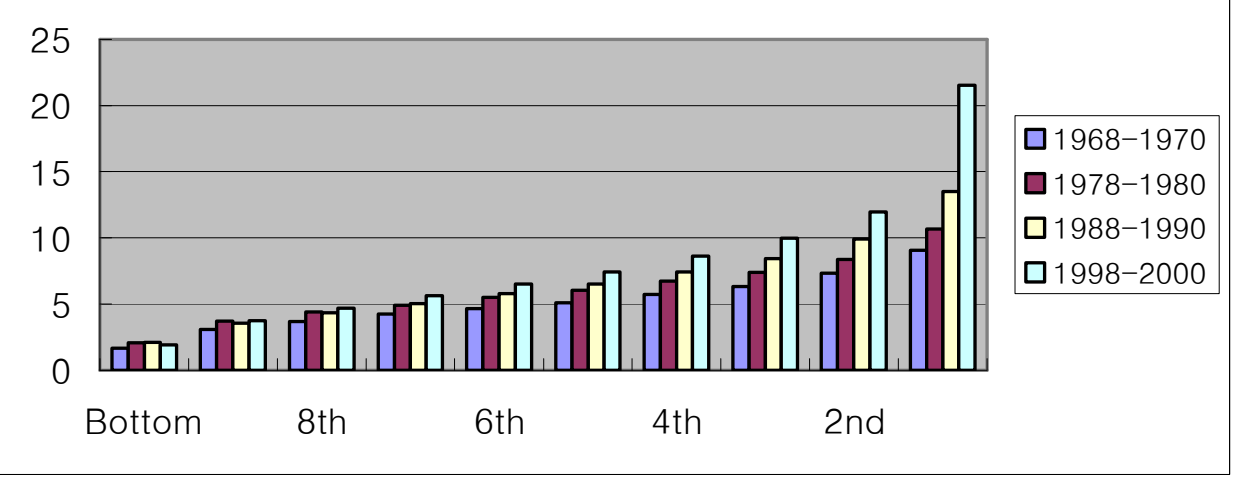

Figure 6

Proportion of Employed Spouses

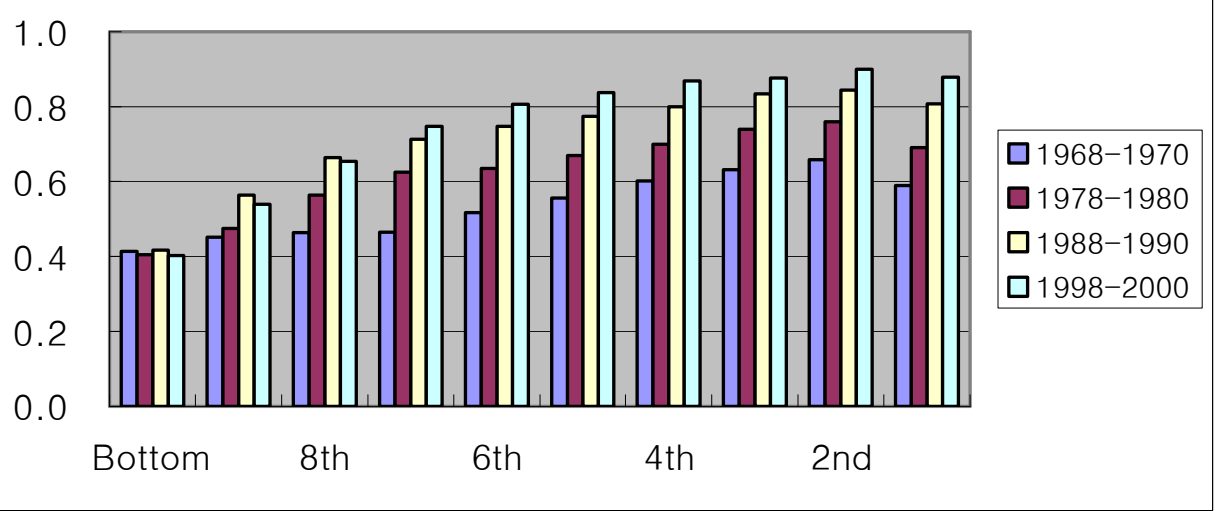


Figure 7

Annual Hours Worked for Employed Spouses

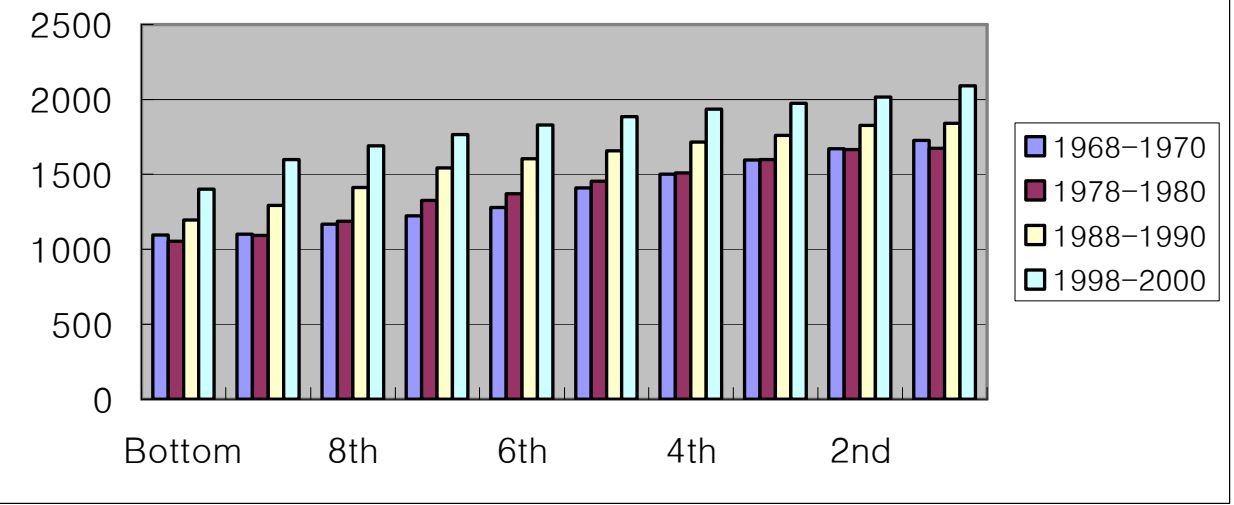

